\title{
Cytotoxic mAb from rheumatic carditis recognizes heart valves and laminin
}

\author{
Jeffrey E. Galvin, ${ }^{1}$ Mark E. Hemric, ${ }^{1}$ Kent Ward, ${ }^{2}$ and Madeleine W. Cunningham ${ }^{1}$ \\ ${ }^{1}$ Department of Microbiology and Immunology, and \\ ${ }^{2}$ Department of Pediatric Cardiology, Children's Heart Center, University of Oklahoma Health Sciences Center, \\ Oklahoma City, Oklahoma, USA \\ Address correspondence to: Madeleine W. Cunningham, Department of Microbiology and Immunology, \\ University of Oklahoma Health Sciences Center, PO Box 26901, Oklahoma City, Oklahoma 73190, USA. \\ Phone: (405) 271-3128; Fax: (405) 271-2217; E-mail: madeleine-cunningham@ouhsc.edu.
}

Received for publication April 20, 1999, and accepted in revised form June 6, 2000.

\begin{abstract}
Anti-streptococcal antibodies cross-reactive with $N$-acetyl- $\beta \mathrm{D}$-glucosamine (GlcNAc) and myosin are present in the sera of patients with rheumatic fever (RF). However, their role in tissue injury is not clear. In this study, we show that anti-GlcNAc/anti-myosin mAb 3.B6 from a rheumatic carditis patient was cytotoxic for human endothelial cell lines and reacted with human valvular endothelium and underlying basement membrane. Reactivity of mAb 3.B6 with the valve was inhibited by human cardiac myosin > laminin > GlcNAc. The mAb 3.B6 epitopes were localized in fragments of human cardiac myosin, including heavy meromyosin (HMM), the S1 subfragment, and two light meromyosin (LMM) peptides containing amino acid sequences KEALISSLTRGKLTYTQQ (LMM 1) and SERVQLLHSQNTSLINQK (LMM 33). A novel feature of mAb 3.B6 was its reactivity with the extracellular matrix protein laminin, which may explain its reactivity with the valve surface. A laminin A-chain peptide (HTQNT) that includes homology to LMM33 inhibited the reactivity of mAb 3.B6 with human valve. These data support the hypothesis that cross-reactive antibodies in rheumatic carditis cause injury at the endothelium and underlying matrix of the valve.
\end{abstract}

J. Clin. Invest. 106:217-224 (2000).

\section{Introduction}

Rheumatic fever (RF) is a nonsuppurative sequela of group-A streptococcal pharyngitis with multiple clinical manifestations including carditis, arthritis, chorea, subcutaneous nodules, and erythema marginatum (1). Although arthritis is the most common manifestation, carditis is the most serious and can lead to valvular scarring. Finding the presence of antibody and complement in heart and valve tissue of RF patients suggested that rheumatic carditis was immunopathologically mediated (2-4). Group-A streptococci induce anti-heart antibodies, and anti-myosin antibodies have been demonstrated in the sera of patients with RF (5-8). Elevated anti-streptococcal antibody responses against the group-A streptococcal carbohydrate antigen persisted in patients with RF and valvular heart disease (9). Furthermore, an immunologic relationship between the group-A polysaccharide and structural glycoproteins of the heart valve was reported (10). Cross-reactive human and murine $\mathrm{mAbs}$ identified streptococcal antigens $\mathrm{M}$ protein $(8,11,12)$ and $N$-acetyl- $\beta$ D-glucosamine (GlcNAc) $(13,14)$, the immunodominant epitope of the group-A streptococcal carbohydrate that share crossreactive epitopes with myosin, tropomyosin, keratin, vimentin, and laminin (11, 12, 15-20). Importantly, human $\mathrm{mAbs}$ produced from patients with RF reacted with $\operatorname{GlcNAc}(5,8,14,21)$, supporting the evidence that anti-carbohydrate antibodies play a role in immunological cross-reactivity. Molecular mimicry between the streptococcal carbohydrate GlcNAc and host antigens may be important in rheumatic valvulitis and in the generation of anti-myosin/anti-GlcNAc antibodies present in patients with disease. Since it has not been determined how cross-reactive antibodies produce tissue injury, our study focused on determining how $\mathrm{mAb}$ 3.B6 from a RF patient might produce cellular injury in rheumatic carditis. Monoclonal antibody 3.B6 reacted with valvular endothelium and laminin, an extracellular matrix protein present in the basement membrane underlying endothelium of heart valves, and was cytotoxic for human umbilical vein endothelial (HUVE) cells. Human cardiac myosin > laminin > GlcNAc and a peptide from laminin A chain inhibited the reaction of mAb $3 . B 6$ with the valve. These data support the hypothesis that anti-streptococcal/anti-myosin antibodies in RF may produce cellular injury at the valvular endothelium and finally link together anti-myosin reactivity with the valve. Monoclonal antibody 3.B6 provides insight to our understanding of how antibodies in patients with RF may recognize the valve surface and increase the risk of rheumatic heart disease.

\section{Methods}

Hybridoma production

Peripheral blood was obtained from a 14-year-old male diagnosed with RF using the Jones criteria. At the time of blood collection the patient had carditis, heart mur- 
mur, polymigrating arthritis, and anti-streptolysin $\mathrm{O}$ titer of 833. Mononuclear cells were separated from whole blood by Histopaque-1077 Hybri-Max (Sigma Chemical Co., St. Louis, Missouri, USA) and stimulated for 1 week with streptococcal peptido-glycan-polysaccharide (PG-PS) complexes $(10 \mu \mathrm{g} / \mathrm{mL})$ in Iscove's modified Dulbecco's medium (IMDM) containing 10\% human $\mathrm{AB}$ serum. The cells were stimulated with pokeweed mitogen $(1 \mu \mathrm{g} / \mathrm{mL})$ in IMDM containing $10 \%$ human $\mathrm{AB}$ serum for an additional week. Cells were washed three times in IMDM without serum and fused with HMMA2.11TG/0 cells (human/mouse myeloma cell line; generous gift from Marshall Posner, Dana Farber Cancer Institute, Boston, Massachusetts, USA) using PEG-1000, as described previously (22). Hybridomas were selected by culture in HAT medium and screened using GlcNAc conjugated to BSA as described (21). Cloning of hybridomas was achieved by limiting dilution and was performed three times. Established clones were maintained in IMDM containing 20\% FBS. Nucleotide sequences of $\mathrm{mAb} 3 . \mathrm{B} 6 \mathrm{~V}$ genes have been reported previously (23).

\section{Antigens}

The following antigens were used to test specificity of human mAb 3.B6: laminin (Sigma Chemical Co.), rM6 (generous gift from Vincent Fischetti, Rockefeller University, New York, New York, USA), GlcNAc-BSA (13), and BSA (Fisher Biotech, Fairlawn, New Jersey, USA). Purity was assessed using SDS-PAGE. Overlapping synthetic peptides corresponding to the light meromyosin (LMM) region of human cardiac myosin beta chain (HCM beta chain) and two peptides from laminin A chain (DRDQLM) (peptide 1) and HTQNT (peptide 2) were generated on a Dupont RAMPS manual peptide synthesizer using the f-moc strategy (24). The sequences and designations of the LMM peptides are as follows: LMM-1, KEALISSLTRGKLTYTQQ; LMM-2 TYTQQLEDLKRQLEEEVK; LMM-3, EEEVKAKNALAHALQSAR; LMM-4, LQSARHDCDLLREQYEEE; LMM-5, EQYEEETEAKAELQRVLSK; LMM-6, RVLSKANSEVAQWRTKYE; LMM-7, RTKYETDAIQRTEELEEA; LMM-8, ELEEAKKKLAQRLQEAEE; LMM-9, QEAEEAVEAVNAKCSSLE; LMM-10, CSSLEKTKHRLQNEIEDL; LMM-11, EIEDLMVDVERSNAAAAA; LMM-12, AAAAALDKKQRNFDKILA; LMM-13, DKILAEWKQKYEESQSEL; LMM-14, SQSELESSQKEARSLSTE; LMM-15, SLSTELFKLKNAYEESLE; LMM-16, EESLEHLETFKRENKNLQ; LMM-17, NKNLQEEISDLTEQLGSS; LMM-18, EQLGSSGKTIHELEKVRKQ; LMM-19, KVRKQLEAEKMELQSALE; LMM-20, LQSALEEAEASLEHEEGKI; LMM-21, EEGKILRAQLEFNQIKAE; LMM-22, NQIKAEIERKLAEKDEEME; LMM-23, DEEMEQAKRNHLRVVDSL; LMM-24, VVDSLQTSLDAETRSRNE; LMM-25, RSRNEALRVKKKMEGDLN; LMM26, EGDLNEMEIQLSHANRMA; LMM-27, ANRMAAEAQKQVKSLQSL; LMM-28, SLQSLLKDTQIQLDDAVR; LMM-29, RANDDLKENIAIVERRNN; LMM-30, IAIVERRNNLLQAELEEL; LMM-31, ELEELRAVVEQTERSRKL; LMM-32, RSRKLAEQELIETSERVQ; LMM-33, SERVQLLHSQNTSLINQK; LMM-34, LINQKKKMDADLSQLQTE; LMM-35, TEV-
EEAVQESRNAEEKAKK; LMM-36, RNAEEKAKKAITDAAMMA; LMM-37, AAMMAEELKKEQDTSAHL; LMM-38, TSAHLERMKKNMEQTIKDL; LMM-39, TIKDLQHRLDEAEQIALK; LMM-40, EQIALKGGKKQLQKLEARV; LMM-41, LEARVRELENELEAEQKR; LMM-42, AEQKRNAESVKGMRKSER; LMM43, RKSERRIKELTYQTEEDR; LMM-44, TEEDRKNLLRLQDLVDKL; LMM-45, LVDKLQLKVKAYKRQAEE; LMM-46, RQAEEAEEQANTNLSKFR; LMM-47, LSKFRKVQHELDEAEERA; LMM-48, AEERADIAESQVNKLRAK; and LMM-49, KLRAKSRDIGTKGLNEE.

Purification of HCM, subfragment 1, and heavy meromyosin

HCM. HCM was purified from human heart tissue according to Tobacman et al. (25), with slight modifications. Heart tissue was homogenized in low-salt buffer (40 mM KCl, 20 mM imidazole, pH 7.0, 5 mM EGTA, 5 mM DTT, $0.5 \mathrm{mM}$ PMSF, and $1 \mu \mathrm{g} / \mathrm{mL}$ leupeptin) on ice for 15 seconds. Washed myofibrils were collected by centrifugation at $16,000 \mathrm{~g}$ for 10 minutes. Pellets were resuspended in high-salt buffer $\left(0.3 \mathrm{M} \mathrm{KCl}, 0.15 \mathrm{M} \mathrm{K}_{2} \mathrm{HPO}_{4}\right.$, $1 \mathrm{mM}$ EGTA, $5 \mathrm{mM}$ DTT, $0.5 \mathrm{mM}$ PMSF, and $1 \mu \mathrm{g} / \mathrm{mL}$ leupeptin), homogenized, and incubated on ice, stirring for 30 minutes to facilitate acto-myosin extraction. After centrifugation, acto-myosin was precipitated by adding 10 volumes of cold water followed by a $\mathrm{pH}$ adjustment to 6.5. DTT was increased to $5 \mathrm{mM}$, and precipitation was allowed to proceed for 30 minutes. Acto-myosin was pelleted by centrifugation at $16,000 \mathrm{~g}$. The acto-myosin pellet was resuspended in high-salt buffer, ammonium sulfate added to $33 \%$, and $\mathrm{KCl}$ concentration increased to $0.5 \mathrm{M}$. After the acto-myosin pellet was dissolved, ATP was added to reach $10 \mathrm{mM}, \mathrm{MgCl}_{2}$ added to reach $5 \mathrm{mM}$, and the solution centrifuged at $20,000 \mathrm{~g}$ for 15 minutes to remove actin filaments. The supernatant was stored at $4^{\circ} \mathrm{C}$ with protease inhibitors: $0.5 \mathrm{mM}$ PMSF, $5 \mu \mathrm{g} / \mathrm{mL}$ TLCK, and $1 \mu \mathrm{g} / \mathrm{mL}$ leupeptin.

Subfragment-1. At lower ionic strength, chymotryptic cleavage yields subfragment-1 (S1) and myosin rod, and at higher ionic strength, chymotryptic cleavage yields heavy meromyosin (HMM) and light meromyosin (LMM). Further cleavage of HMM yields S1 and S2 subfragments. S1 was produced from purified HCM according to Tobacman et al., with slight modification (25). Myosin was dialyzed against digestion buffer $(0.1 \mathrm{M}$ $\mathrm{NaCl}, 0.01 \mathrm{M}$ imidazole-HCl, pH 7, and 0.001 M DTT), and cleaved with a $1: 100 \mathrm{wt} / \mathrm{wt}$ ratio of $\alpha$-chymotrypsin to myosin for 15 minutes at $25^{\circ} \mathrm{C}$. The reaction was terminated by the addition of PMSF to a final concentration of $0.3 \mathrm{mM}$. Rod and uncleaved myosin were precipitated by dialysis in a low-salt solution $(10 \mathrm{mM} \mathrm{NaCl}, 10$ mM imidazole, pH 7.0, 1 mM DTT) and separated from soluble $S 1$ by centrifugation at 200,000 $\mathrm{g}$. S1 purity was assessed using SDS-PAGE, and in some cases S1 was purified by ammonium sulfate precipitation and/or DEAE ion-exchange chromatography.

HMM subfragment. HMM subfragment of HCM was prepared according to a described procedure with slight modification (26). HMM was prepared by digest- 
ing myosin in $0.6 \mathrm{M} \mathrm{KCl}, 2 \mathrm{mM} \mathrm{MgC1} 1_{2}, 1 \mathrm{mM}$ DTT, and $0.01 \mathrm{M}$ Tris- $\mathrm{HCl}(\mathrm{pH} 7.6)$, with 1:100 wt/wt ratio of $\alpha$-chymotrypsin to myosin for 10 minutes at $25^{\circ} \mathrm{C}$. The reaction was terminated by adding PMSF to a final concentration of $0.3 \mathrm{mM}$. LMM and uncleaved myosin were precipitated by dialysis in low salt $(0.03 \mathrm{M} \mathrm{KCl}$, $0.01 \mathrm{M}$ potassium phosphate, $\mathrm{pH} 6.3,1 \mathrm{mM}$ DTT, and $1 \mathrm{mM} \mathrm{MgCl} 2$ ) and separated from soluble HMM by centrifugation at 200,000 g. HMM purity was assessed using SDS-PAGE. In some cases HMM was purified by ammonium sulfate precipitation and/or DEAE ionexchange chromatography.

\section{ELISA}

Antigens were coated onto Immunolon 4 ELISA plates (Dynatech Laboratories, Chantilly, Virginia, USA) at 10 $\mu \mathrm{g} / \mathrm{mL}$ in $0.015 \mathrm{M}$ carbonate $/ 0.03 \mathrm{M}$ bicarbonate ( $\mathrm{pH}$ 9.6) buffer overnight at $4^{\circ} \mathrm{C}$. After two washes with PBS containing $0.05 \%$ Tween (PBS-Tween), wells were blocked with $1 \% \mathrm{BSA}$ in PBS for 1 hour at $37^{\circ} \mathrm{C}$. Wells were washed two times with PBS-Tween, and $\mathrm{mAb}(10 \mu \mathrm{g} / \mathrm{mL})$ was incubated overnight at $4^{\circ} \mathrm{C}$. After three PBS-Tween washes, alkaline phosphatase-labeled goat anti-human IgM (1:500; Sigma Chemical Co.) was incubated in the wells for 1 hour at $37^{\circ} \mathrm{C}$. Finally, $50 \mu \mathrm{L}$ substrate, $p$-nitrophenyl phosphate (Sigma 104 phosphatase substrate), prepared in diethanolamine buffer at $1 \mathrm{mg} / \mathrm{mL}$ was added. OD was measured at $405 \mathrm{~nm}$ with an automated ELISA reader (Dynatech MR 700). Results were expressed as the mean of triplicate wells.

\section{Competitive-inhibition ELISA}

Competitive-inhibition ELISA was performed in triplicate as described $(11,27)$. Inhibitor solutions (HCM, GlcNAc-BSA, BSA, or laminin) were prepared in PBS and mixed with an equal volume of mAb 3.B6 $(10 \mu \mathrm{g} / \mathrm{mL})$, incubated at $37^{\circ} \mathrm{C}$ for 1 hour and overnight at $4^{\circ} \mathrm{C}$. Fifty microliters of mAb $3 . B 6$ mixture was added to wells coated with HCM, GlcNAc-BSA, or BSA $(10 \mu \mathrm{g} / \mathrm{mL})$. The remainder of the assay was performed as described above. Percentage of inhibition was calculated as follows: $100 \times\left(1-\left[\mathrm{A}_{410}\right.\right.$ inhibitor $+\mathrm{mAb} 3 . \mathrm{B} 6 / \mathrm{A}_{410} \mathrm{PBS}+\mathrm{mAb}$ 3.B6]). Maximal (100\%) reactivity was determined by incubating $\mathrm{mAb} 3 . \mathrm{B} 6$ with PBS without inhibitor.

\section{Dot blot}

Fifty micrograms of each peptide or protein was applied to nitrocellulose membrane using a vacuum dot-blot apparatus (Bio-Rad Laboratories, Hercules, California, USA). The membrane was blocked with 5\% skim milk for 3 hours at $37^{\circ} \mathrm{C}$, washed twice with PBS-Tween, and incubated overnight at $4^{\circ} \mathrm{C}$ with $\mathrm{mAb}$ 3.B6. After 5 PBSTween washes, the membrane was incubated with horseradish peroxidase-conjugated goat anti-human IgM (diluted 1:250; Sigma Chemical Co.) for 1 hour at $37^{\circ} \mathrm{C}$, and washed 5 times with PBS-Tween, followed by a wash with $0.05 \mathrm{M}$ Tris (pH 7.5). Finally, $0.25 \mathrm{mg} / \mathrm{mL}$ alpha-chloronapthol (Sigma Chemical Co.) and $17 \mu \mathrm{L}$ of $30 \%$ hydrogen peroxide in $100 \mathrm{~mL}$ of $0.05 \mathrm{M}$ Tris buffer was used as substrate to detect mAb 3.B6-reactive peptides. Negative control wells were BSA or PBS.

Immunohistochemistry staining of human valves and myocardium

Human mitral valves and myocardium were fixed overnight in 10\% buffered formalin (Fisher Scientific, Pittsburgh, Pennsylvania, USA), sectioned (4-5 $\mu \mathrm{m}$ thick) and mounted on Microprobe ProbeOn Plus slides (Fisher). Mounted tissues were baked at $60^{\circ} \mathrm{C}$ for 20 minutes and deparaffinized using a 3:1 ratio of Hemo$\mathrm{D}$ (Fisher) to xylene. After rehydration in graded ethanol washes, tissues were washed twice with PBS, blocked with Protein Blocker (BioGenex, San Ramon, California, USA) for 15 minutes at room temperature, and washed twice with PBS. Monoclonal antibody $3 . B 6(10 \mu \mathrm{g} / \mathrm{mL})$ or isotype control human IgM antibody $(10 \mu \mathrm{g} / \mathrm{mL}$; Sigma Chemical Co.) were incubated on tissues for 30 minutes at room temperature followed by three PBS washes. Biotin-conjugated goat anti-human IgM antibodies (diluted 1:500; Jackson ImmunoResearch, West Grove, Pennsylvania, USA) were incubated on tissues for 30 minutes at room temperature, followed by three washes in PBS. Alkaline phosphatase-conjugated streptavidin (Jackson ImmunoResearch) was incubated on the tissues at $1 \mu \mathrm{g} / \mathrm{mL}$ for 30 minutes at room temperature. After three washes in PBS, antibody binding was detected with Fast Red substrate (BioGenex) against a counterstain of Mayer's hematoxylin (BioGenex). Stained slides were mounted with crystal mount (Fisher), dried, and coverslipped using permount (Sigma Chemical Co.) as the mounting media.

Competitive inhibition of reactivity of $\mathrm{mAb} 3 . \mathrm{B} 6$ with human valve tissue sections

A competitive inhibition assay was used to test the antigens HCM, laminin, GlcNAc-BSA, BSA alone, and

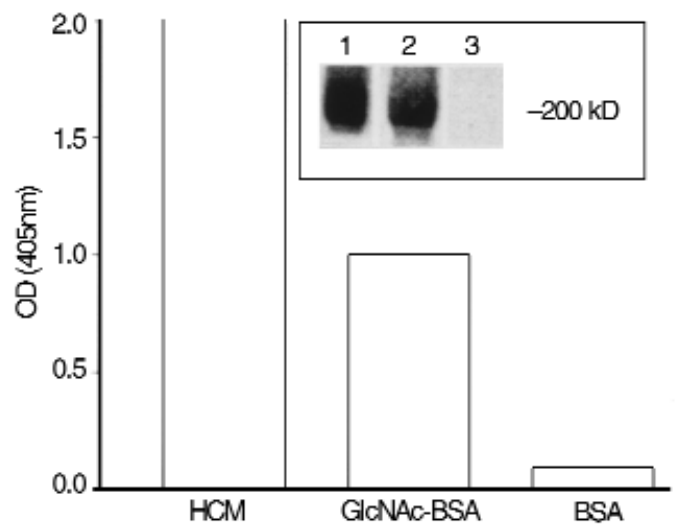

\section{Figure 1}

Reactivity of human mAb 3.B6 with HCM, GlcNAc-BSA, and BSA in the ELISA. Results shown as OD measured at $405 \mathrm{~nm}$. Inset shows a Western blot of HCM reacted with mAb 3.B6 (lane 2); Amido black stain of HCM (lane 1) and negative control blot reacted with peroxidase-conjugated anti-human IgM antibodies (lane 3 ) are also shown. Molecular mass is indicated. 
Figure 2

Inhibition of mAb 3.B6 by HCM and GlcNAc-BSA. Monoclonal antibody 3.B6 $(10 \mu \mathrm{g} / \mathrm{mL})$ was mixed $1: 1$ with increasing amounts of inhibitor (0 to 500 $\mu \mathrm{g} / \mathrm{mL}$ ), and binding of free $\mathrm{mAb}$ to immobilized $\mathrm{HCM}(\mathbf{a})$ or GlcNAc-BSA $(\mathbf{b})$ on the microtiter plate was detected by ELISA. The concentration of HCM required to inhibit $50 \%$ of binding of $\mathrm{mAb} 3 . \mathrm{B} 6$ to GlcNAc-BSA was $67 \mu \mathrm{g} / \mathrm{mL}(\mathbf{b})$. The concentration of GlcNAc-BSA required to inhibit $50 \%$ of binding of $\mathrm{mAb} 3 . \mathrm{B} 6$ to $\mathrm{HCM}$ was more than $500 \mu \mathrm{g} / \mathrm{mL}$ (a). BSA alone did not inhibit mAb 3.B6. Inhibitors are as follows: squares, HCM; diamonds, GlcNAc-BSA; circles, BSA. Percentage of inhibition was calculated using the following formula: $100 \times\left(1-\left[\mathrm{A}_{410}\right.\right.$ inhibitor $+m A b 3 . B 6 / A_{410}$ PBS + mAb 3.B6]). a

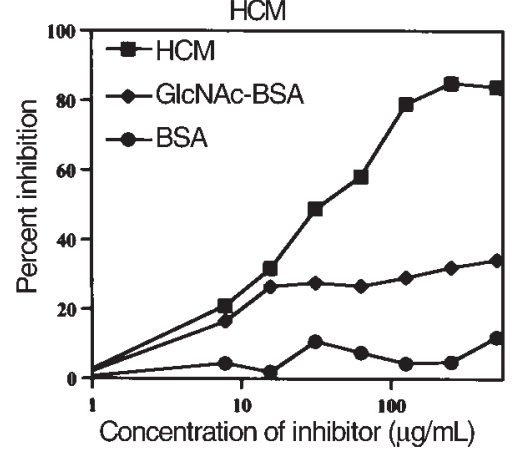

b

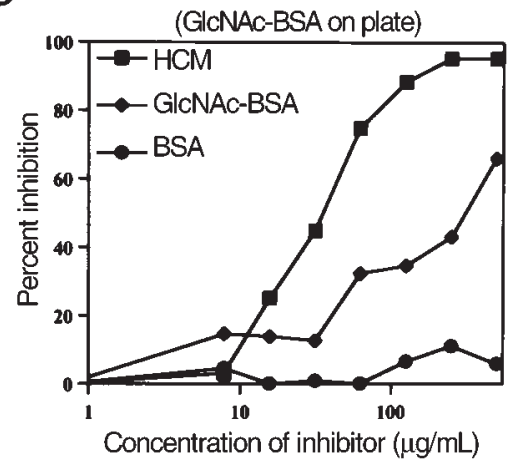

laminin A-chain peptides 1 and 2 for inhibition of $\mathrm{mAb}$ $3 . \mathrm{B} 6$ reactivity with human valve sections. Inhibitors were mixed with $\mathrm{mAb} 3 . \mathrm{B} 6$ at a final concentration of $500 \mu \mathrm{g} / \mathrm{mL}$ and incubated at $37^{\circ} \mathrm{C}$ and overnight at $4^{\circ} \mathrm{C}$ before applying the $\mathrm{mAb}$ to tissue sections of human valve. Detection of mAb binding to tissues was performed as described above.

Cytotoxicity assay

HUVE cells were isolated and cultured in Medium 199 (GIBCO BRL, Grand Island, New York, USA) with 20\% FBS, $10 \mu \mathrm{g} / \mathrm{mL}$ endothelial cell growth factor (Sigma Chemical Co.), $90 \mu \mathrm{g} / \mathrm{mL}$ porcine heparin (Sigma Chemical Co.), and penicillin and streptomycin (GIBCO BRL), as described previously (28). HUVE cells cultured in 96well flat-bottom plates at $2 \times 10^{4}$ cells/well overnight at $37^{\circ} \mathrm{C}$ and $5 \% \mathrm{CO}_{2}$ were labeled for 2 hours with 5 $\mu \mathrm{Ci} /$ well of sodium chromate ${ }^{51}$ (Dupont NEN, Boston, Massachusetts, USA). Labeled HUVE cells were washed three times with Medium 199 containing 20\% FBS and incubated with the same media for an additional hour at $37^{\circ} \mathrm{C}$ and $5 \% \mathrm{CO}_{2}$. After three washes with Medium 199 without FBS, mAb 3.B6 and IgM isotype controls were added $(100 \mu \mathrm{L} /$ well $)$ and cells incubated at $37^{\circ} \mathrm{C}$ for 1 hour. Then, $100 \mu \mathrm{L}$ of guinea pig complement (Sigma Chemical Co.) was added to each well followed by a 1hour incubation at $37^{\circ} \mathrm{C}$. Supernatants were collected from 96-well microtiter plates using the Skatron harvesting system (Skatron Inc., Sterling, Virginia, USA). Counts per minute were determined by a 1282 Compugamma counter (LKB Wallac, Gaithersburg, Maryland, USA). Percentage of lysis was calculated using the a

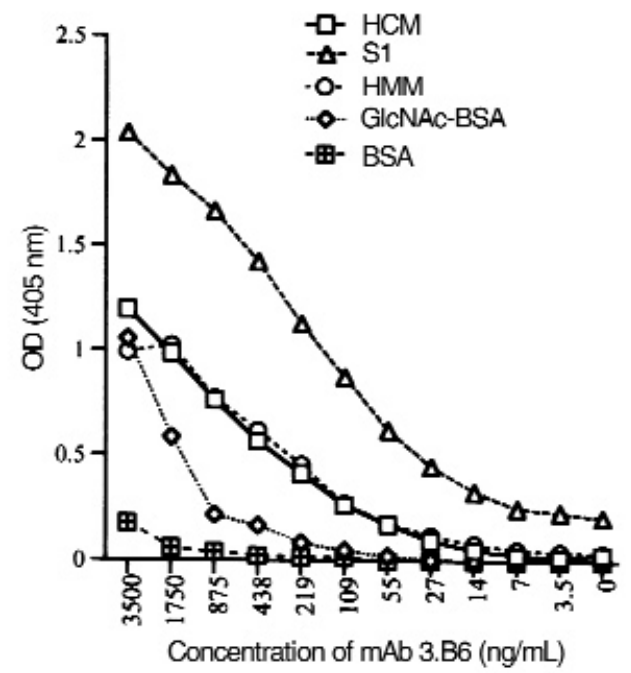

b

\begin{tabular}{|rllllll|}
\hline PBS & LMM1 & LMM2 & LMM3 & LMM4 & LMM5 \\
\hline LMM6 & LMM7 & LMM8 & LMM9 & LMM10 & LMM11 \\
\hline LMM12 & LMM13 & LMM14 & LMM15 & LMM16 & LMM17 \\
\hline PBS & LMM18 & LMM19 & LMM20 & LMM21 & LMM22 \\
\hline LMM23 & LMM24 & LMM25 & LMM26 & LMM27 & LMM28 \\
\hline LMM29 & LMM30 & LMM31 & LMM32 & LMM33 & LMM34 \\
\hline LMM35 & LMM36 & LMM37 & LMM38 & LMM39 & LMM40 \\
\hline LMM41 & LMM42 & LMM43 & LMM44 & LMM45 & LMM46 \\
\hline LMM47 & LMM48 & LMM49 & & & \\
\hline
\end{tabular}

Figure 3

(a) Dose-response curve of mAb 3.B6 reacted with HCM, HCM subfragments (HMM and S1), GlcNAc-BSA, and BSA by ELISA. Although $\mathrm{mAb} 3 . \mathrm{B} 6$ reacted with $\mathrm{HCM}, \mathrm{HMM}$, and GlcNAc, the strongest reactivity was with the S1 subfragment. (b) Reactivity of mAb $3 . \mathrm{B} 6$ with human LMM peptides in the immunodot blot assay. Fifty micrograms of peptide were adsorbed onto nitrocellulose and reacted with $\mathrm{mAb}$ 3.B6 $(10 \mu \mathrm{g} / \mathrm{mL})$; mAb 3.B6 binding was detected by peroxidase-conjugated anti-human IgM antibodies. Samples were performed in duplicate. PBS was the negative control in which no peptide was blotted onto nitrocellulose. Monoclonal antibody 3.B6 reacted with LMM 1, LMM 33, and weakly with LMM 17, as shown. 


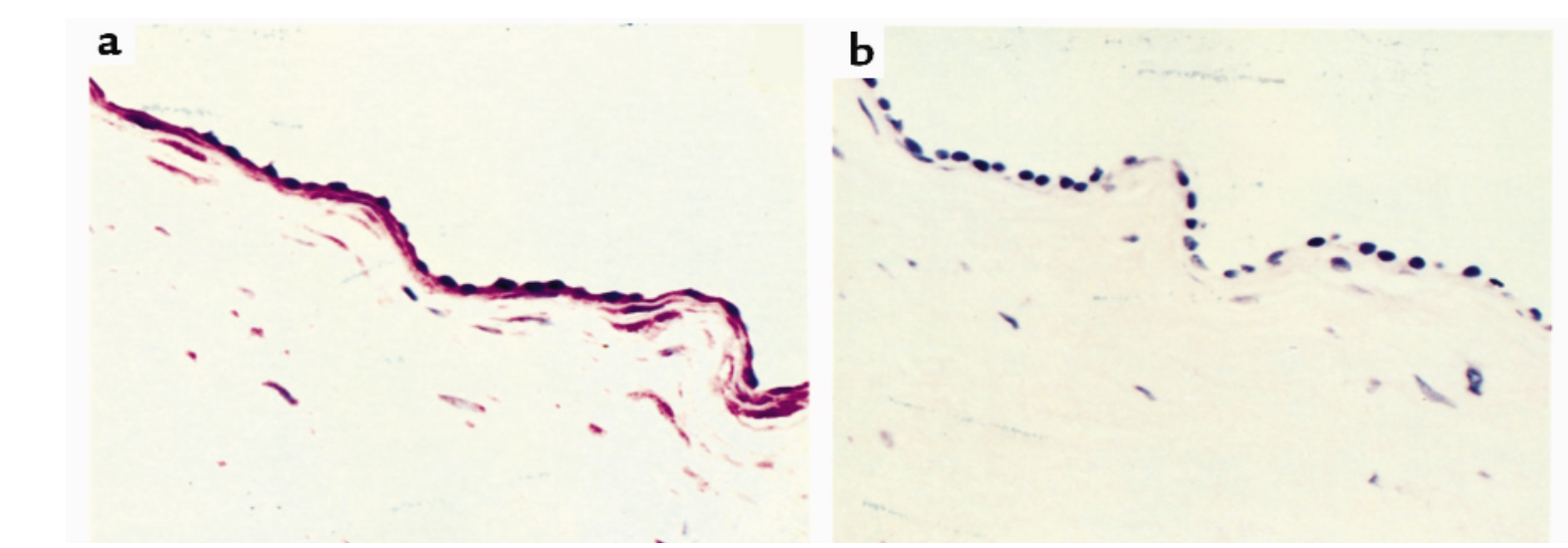

\section{Figure 4}

(a) Reactivity of mAb 3.B6 with normal human valve. Formalin-fixed human mitral valves were processed by routine histochemical techniques and incubated with $\mathrm{mAb} 3 . \mathrm{B} 6$ at $10 \mu \mathrm{g} / \mathrm{mL}$. Monoclonal antibody 3.B6 binding was detected using biotin-conjugated anti-human antibodies and alkaline phosphatase-labeled streptavidin followed by phosphatase substrate. (b) Control valve sections were negative after reaction with human IgM at $10 \mu \mathrm{g} / \mathrm{mL}$.

following equation: \% lysis $=[$ (test release - spontaneous release) / (maximum release - spontaneous release) $] \times$ 100. Spontaneous release was measured using IMDM without antibody, and maximum release was measured using $1 \mathrm{~N} \mathrm{HCl}$. Controls were three human IgM mAbs without cytolytic activity against HUVE.

\section{Results}

Characterization of $m A b$ 3.B6. Monoclonal antibody 3.B6 reacted with GlcNAc and cardiac myosin (Figure 1, inset, lanes 1 and 2) and in previous studies reacted with tropomyosin, vimentin, and weakly with keratin and recombinant M6 protein (rM6) (23). Competitive-inhibition ELISA was employed to determine avidity of $\mathrm{mAb}$ 3.B6 for HCM and GlcNAc. The concentration of HCM that inhibited binding of $\mathrm{mAb} 3 . \mathrm{B} 6$ to GlcNAc-BSA by $50 \%$ was $67 \mu \mathrm{g} / \mathrm{mL}$ (Figure $2 \mathrm{~b}$ ), whereas a much higher concentration of GlcNAc-BSA (> $1000 \mu \mathrm{g} / \mathrm{mL}$ ) was required to inhibit binding of $\mathrm{mAb} 3 . \mathrm{B} 6$ to $\mathrm{HCM}$ by $50 \%$ (Figure 2a). The mAb 3.B6 binding avidity was HCM > GlcNAc-BSA in the ELISA. Inhibition by BSA was less than $10 \%$ at all concentrations tested (Figure 2 , $a$ and $b$ ).

\section{Figure 5}

(a) Inhibition of mAb 3.B6 binding to GlcNAc-BSA by laminin. Monoclonal antibody $3 . \mathrm{B} 6(10 \mu \mathrm{g} / \mathrm{mL})$ was mixed with increasing amounts of inhibitor $(0-500 \mu \mathrm{g} / \mathrm{mL})$, and binding of $\mathrm{mAb}$ to GlcNAc-BSA on the microtiter plate was detected by ELISA; mAb 3.B6 binding to BSA coated wells was negative. Inhibitors are as follows: squares, laminin; circles, BSA. Percentage of inhibition was calculated by the formula used in Figure 2. (b) Reactivity of mAb 3.B6 with laminin in the immunodot blot assay. Fifty micrograms laminin was adsorbed onto nitrocellulose and reacted with $\mathrm{mAb} 3 . \mathrm{B} 6(10 \mu \mathrm{g} / \mathrm{mL})$, and $\mathrm{mAb} 3 . \mathrm{B} 6$ binding to laminin was detected by peroxidase-conjugated anti-human IgM antibodies followed by substrate. Monoclonal antibody 3.B6 did not bind to BSA, and the IMDM medium control was not laminin reactive.
To localize the mAb $3 . \mathrm{B} 6$ epitope(s) in HCM, S1 and HMM subfragments, and LMM, peptides were reacted with $\mathrm{mAb}$ 3.B6. S1 and HMM subfragments reacted with $\mathrm{mAb} 3 . \mathrm{B} 6$ in the ELISA (Figure 3a), suggesting that mAb $3 . B 6$ recognized epitope(s) in both fragments. However, mAb 3.B6 reacted with S1 more intensely than intact HCM (Figure 3a). Monoclonal antibody 3.B6 was tested for reactivity with 49 overlapping synthetic peptides corresponding to the LMM rod region of HCM (Figure 3b) and reacted with LMM 1 (residues 1295-1312), LMM 33 (amino acids 1711-1728), and weakly with LMM 17 (residues 1503-1520; Figure 3b).

Reactivity of mAb $3 . B 6$ with human valvular endothelium. Experiments were performed to test the ability of $\mathrm{mAb}$ 3.B6 to react with human valvular endothelium. Formalin-fixed normal human heart valves were reacted with mAb $3 . B 6$ using immunohistochemistry techniques. Monoclonal antibody 3.B6 reacted intensely with endothelial cells at the valve surface and the underlying basement membrane/extracellular matrix (Figure 4a). It also reacted with sections of human myocardium (data not shown). Control sections of

a

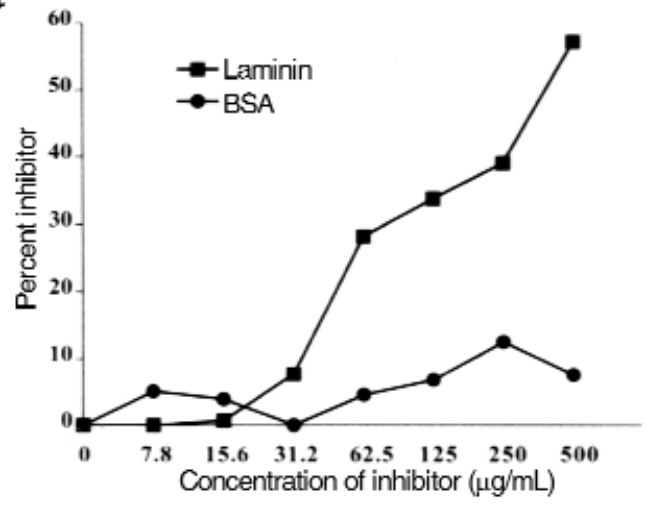

b

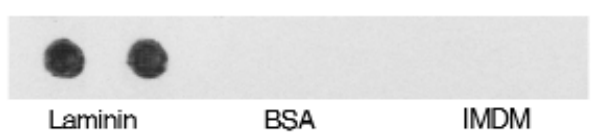




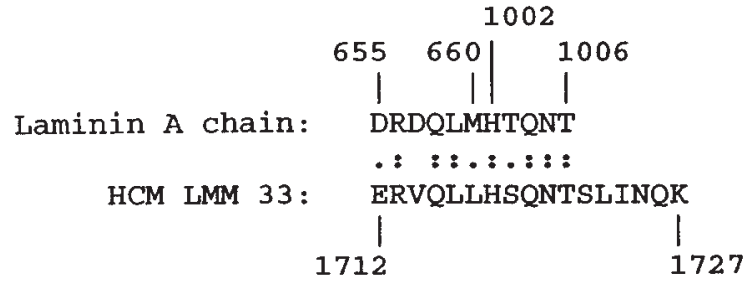

Figure 6

Amino acid sequence alignment of laminin A chain and HCM LMM 33. Amino acid sequence designations of two homologous regions in the laminin A chain are indicated above and HCM below in the figure. The sequence of laminin A chain (44) and myosin heavy chain $\beta$ (45) have been described. The sequences shown are $64 \%$ identical and $91 \%$ homologous. (:), Identity; (.), conserved amino acid substitution.

human valve and myocardium (not shown) were reacted with human IgM at the same concentration as $\mathrm{mAb}$ $3 . \mathrm{B} 6$ and were negative (Figure 4b).

Reactivity of $m A b 3 . B 6$ with laminin. Binding inhibition assays were performed to determine if $\mathrm{mAb} 3 . \mathrm{B} 6$ could recognize soluble extracellular matrix proteins such as laminin. Soluble laminin inhibited mAb 3.B6 binding to GlcNAc-BSA in a dose-dependent manner (Figure $5 a)$. The mAb 3.B6 recognized laminin in the immunodot blot assay (Figure 5b). Comparison of 3.B6-positive LMM peptides with laminin revealed homology between LMM33 and two different regions of the laminin A chain shown in Figure 6.

Competitive inhibition of $m A b 3 . B 6$ reactivity with human valve. $\mathrm{HCM}$, laminin, GlcNAc-BSA, BSA, and laminin A-chain peptides 1 and 2 were tested to determine their capacity to inhibit binding of $\mathrm{mAb} 3 . \mathrm{B} 6$ to human valve. Figure $7 \mathrm{a}$ illustrates binding of $\mathrm{mAb} 3 . \mathrm{B} 6$ with valve and underlying matrix. Figure $7 \mathrm{~b}$ illustrates inhibition of mAb 3.B6 by HCM, and Figure 7c shows inhi- bition by laminin. Figure $7 \mathrm{~d}$ shows very weak inhibition by GlcNAc-BSA, and no inhibition by BSA alone (not shown) was seen. Figure 7, e and f, respectively, show that laminin A-chain peptide 1 did not inhibit whereas peptide 2 did inhibit $\mathrm{mAb} 3 . \mathrm{B} 6$ binding to valve. In summary, $\mathrm{mAb} 3 . \mathrm{B} 6$ valve reactivity was inhibited by cardiac myosin > laminin > GlcNAc and by laminin A-chain peptide 2.

Cytotoxic activity of $m A b 3 . B 6$ on HUVE cells. Since human $\mathrm{mAb} 3 . \mathrm{B} 6$ reacted with valvular endothelium, we investigated the possibility that mAb $3 . \mathrm{B} 6$ might be cytotoxic for primary HUVE cells in the presence of complement; mAb $3 . \mathrm{B} 6$ demonstrated $40 \%$ lysis of HUVE cells in the presence of complement (Figure 8a). Human IgM anti-streptococcal mAb 1.C8 did not produce lysis of the HUVE cells after addition of complement. Four other primary HUVE cell lines developed were susceptible to lysis by $\mathrm{mAb} 3 . \mathrm{B} 6$ as compared with the human IgM isotype control mAb 1.C8 (Figure 8b).

\section{Discussion}

We demonstrated previously that anti-streptococcal mAbs are polyreactive and recognized streptococcal and mammalian antigens $(8,11,12,16,17,20)$. Murine anti-streptococcal antibodies were categorized into three groups based on their antigen reactivity. Group 1 reacted with alpha-helical coiled-coil molecules such as myosin, $M$ protein, tropomyosin, and vimentin, whereas group 2 was antinuclear and reacted with DNA and myosin $(11,16,29)$. Human anti-streptococcal mAbs and antibodies in the sera of patients with RF are not antinuclear and do not react with DNA $(5,8,23)$. A third group of cross-reactive anti-streptococcal murine and human mAbs recognized GlcNAc, the immunodominant carbohydrate antigen of group A streptococci $(13,14,21)$. The present work describes a novel
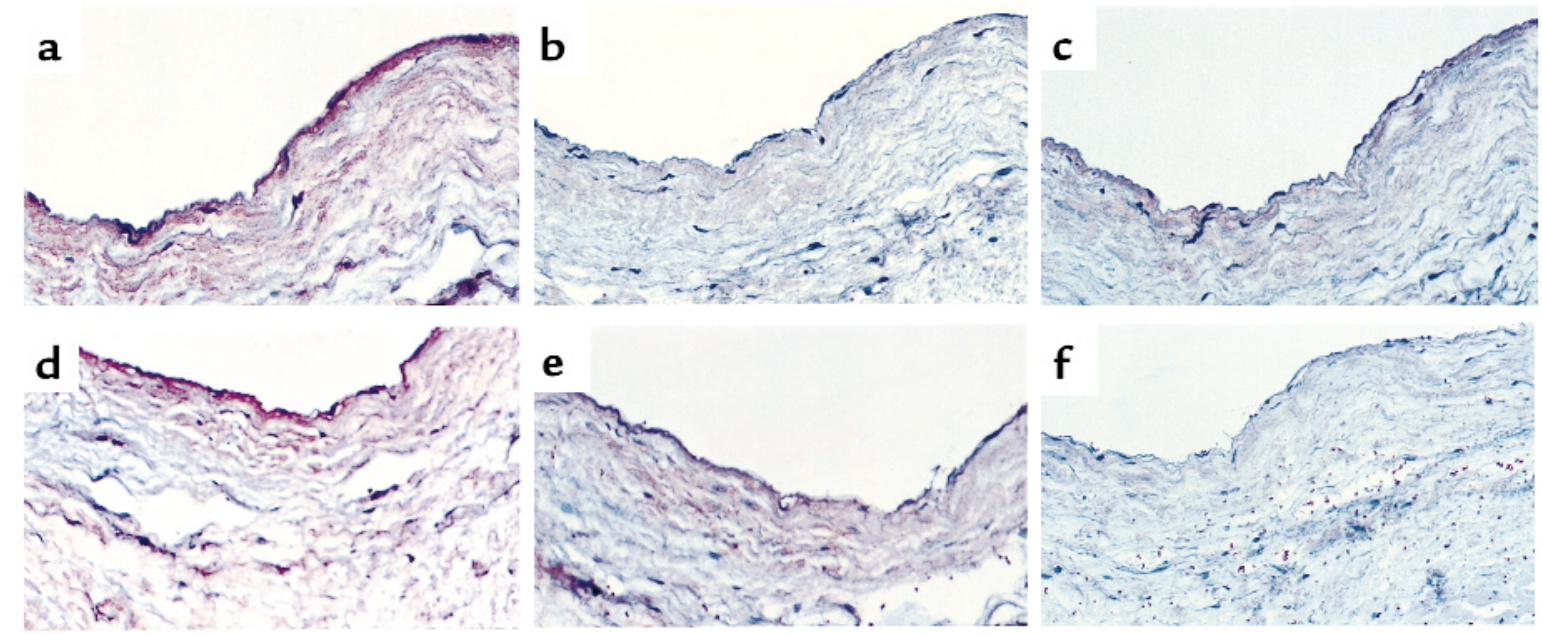

Figure 7

Competitive inhibition of $\mathrm{mAb} 3$. B6 reactivity with human valve tissue sections. (a) Illustrates the reaction of $\mathrm{mAb} 3$. B6 with valve endothelium and underlying matrix; (b) inhibition of mAb 3. B6 by HCM; (c) inhibition of mAb 3. B6 by laminin; (d) very weak inhibition by GlcNAcBSA, whereas inhibition with BSA alone (not shown) was equivalent to Figure 7a; (e) no inhibition by laminin A-chain peptide DRDQLM (residues 655-660); (f) inhibition by laminin A-chain peptide HTQNT (residues 1002-1006). Reactivity of mAb 3 .B6 against human valve was inhibited by cardiac myosin > laminin > GlcNAc, and laminin A-chain peptide HTQNT inhibited > laminin A-chain peptide DRDQLM . 
anti-streptococcal/anti-myosin mAb (3.B6) produced from a patient with active rheumatic carditis and arthritis, which reacted with valvular endothelium and was cytotoxic for human endothelial cells.

Other researchers have demonstrated the presence of cytotoxic anti-endothelial cell antibodies in the serum of patients with Kawasaki's disease $(30,31,32)$, hemolytic-uremic syndrome (33), and individuals with carotid atherosclerosis (34). Since mAb $3 . \mathrm{B} 6$ reacted with human valve endothelium, we determined if $\mathrm{mAb}$ 3.B6 was cytotoxic for endothelial cells. Five HUVE cell lines were susceptible to $\mathrm{mAb} 3 . \mathrm{B} 6$ lysis in the presence of complement. Our data suggest that a human antimyosin antibody could potentially recognize surface molecules on endothelial cells and valve.

Further evidence that mAb $3 . \mathrm{B} 6$ may be a potentially damaging antibody at the valve surface is its recognition of laminin, a glycoprotein located in basement membrane underlying valvular endothelium (35). The unique location of laminin in the extracellular matrix and basement membrane makes it an ideal target for polyreactive anti-streptococcal antibodies in rheumatic carditis patients. Endothelial cell alterations may occur under shear stress due to turbulent blood flow at the valve surface $(36,37)$. Under these conditions, endothelial alteration may result in exposure of the underlying basement membrane/extracellular matrix. Exposure of laminin may contribute to binding of cross-reactive antibodies and subsequent inflammation of valvular tissue in rheumatic patients. Indeed, scanning electronmicroscopy studies have demonstrated that valves from patients with rheumatic heart disease have areas of denuded endothelium resulting in exposure of the subendothelial compartment (38). Laminin is secreted by cultured endothelial cells (39), and it is possible that mAb 3.B6 recognized laminin on their surface.

Monoclonal antibody 3.B6 recognized cardiac myosin most strongly, and multiple epitopes were identified within the HCM molecule as demonstrated by reactivity with S1, HMM, and two LMM peptides. Of particular interest was the reaction of $\mathrm{mAb} 3 . \mathrm{B} 6$ with peptide LMM 33 of HCM. Peptide LMM 33 was found to contain homologous amino acid sequences with the $\mathrm{A}$ chain of laminin (Figure 7). Reaction of the two synthesized peptide regions of the laminin A chain revealed that peptide residues 1002-1006 inhibited the reaction of $\mathrm{mAb} 3 . \mathrm{B} 6$ with valve endothelium and underlying matrix. The data suggest that epitopes such as HTQNT exposed at the surface of the valve can be recognized by the anti-streptococcal/anti-myosin mAb 3.B6.

Our studies of mAb 3.B6 are consistent with reports of antibody deposition on valvular tissue and in myocardium in RF patients at autopsy (3). Dudding and Ayoub reported anti-group A carbohydrate antibodies persistently elevated in patients with valvulitis (9), and surgical removal of inflamed valves resulted in a significant decrease in levels of anti-group A carbohydrate antibodies present in serum (40). We demonstrated previously that murine anti-streptococcal antibodies recognized valvular endothelium (41). Collectively, these studies suggest that antibodies reactive with valvular tissue may be present in rheumatic carditis patients and that the valve may serve as a source of antigen to maintain the presence of these autoantibodies. If autoantibody-mediated damage to endothelium occurs, the endothelial cells would become activated and upregulate expression of cell adhesion molecules that allow inflammatory cells to enter the valve. It is possible that autoantibodies induced after streptococcal infection may be responsible for initiation of valvular inflammation. The discovery of mAb 3.B6 is the first evidence, to our knowledge, of a human anti-myosin/anti-streptococcal $\mathrm{mAb}$ that reacts with the valve surface and underlying matrix and that is cytotoxic for human endothelial cells. The study provides important insights into the
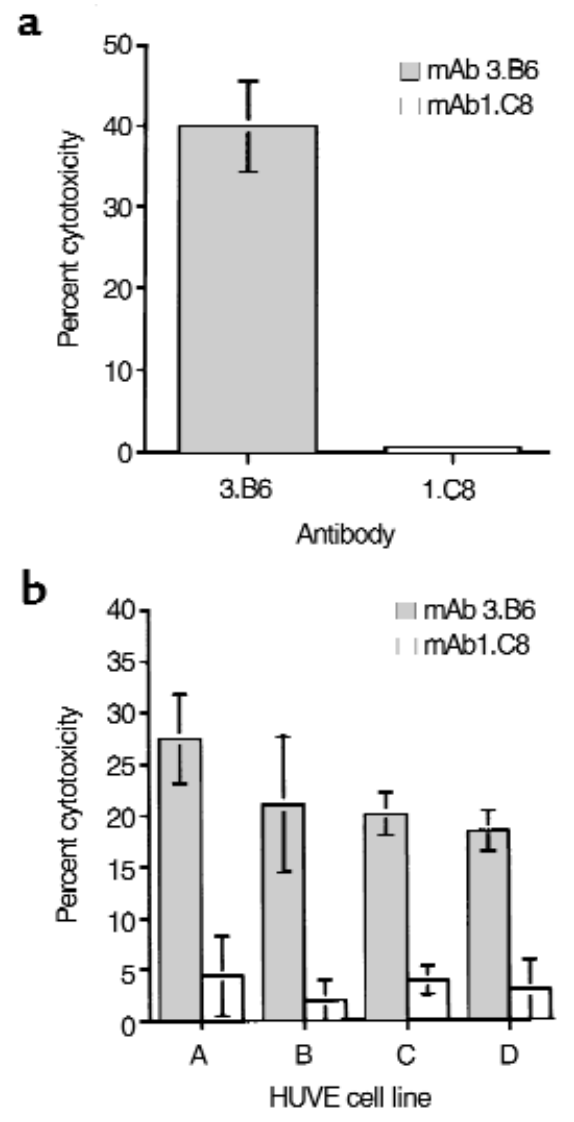

\section{Figure 8}

(a) Cytotoxic activity of human mAb 3.B6 on HUVE cells. HUVE cells were isolated from three umbilical cords and pooled as described (28). Then, mAb 3.B6 and control mAb 1.C8 (human IgM anti-streptococcal/anti-myosin antibody) were tested at $10 \mu \mathrm{g} / \mathrm{mL}$. Percentage of cytotoxicity was determined by the formula: $\%$ lysis $=[$ (test release - spontaneous release)/(maximum release - spontaneous release)] $\times 100$. Spontaneous release was measured using IMDM without antibody, and maximum release was measured using $1 \mathrm{~N} \mathrm{HCl}$. (b) Cytotoxic activity of mAb 3.B6 on four primary HUVE cell lines that were isolated from different umbilical cords. Monoclonal antibody 3.B6 induced cytotoxicity (gray bars) and no cytotoxicity observed by isotype control mAb 1.C8 (open bars). Percentage of cytotoxicity was determined by the formula as in a. Spontaneous release was measured using IMDM without antibody, and maximum release was measured using $1 \mathrm{~N} \mathrm{HCl}$. 
possible mechanism by which valvular damage might occur during RF. The hypothesis that pathogenic and cross-reactive autoantibodies can be generated by bacterial or foreign antigens is an important concept in autoimmunity $(17,42,43)$.

\section{Acknowledgments}

Gratitude is expressed to Janet Heuser for expert technical assistance, Ken Jackson and the W. K. Warren Molecular Biology Resource Facility at the University of Oklahoma Health Sciences Center for peptide synthesis, and to Marshall Posner and Vincent Fischetti for the kind gifts of HMMA2.11TG/0 cell line and recombinant M6 protein, respectively. This work was supported by grants HL35280 and HL56267 from the National Heart, Lung, and Blood Institute to M.W. Cunningham.

1. Bisno, A.L. 1995. Nonsuppurative poststreptococcal sequelae: rheumatic fever and glomerulonephritis. In Principles and practice of infectious diseases. G.L. Mandell, J.E. Bennett, and R. Dolin, editors. Churchill Livingston. New York, New York, USA. 1799-1810.

2. Kaplan, M.H., and Dallenbach, F.D. 1960. Immunologic studies of heart III. Occurrence of bound gamma globulin in auricular appendages from rheumatic hearts. Relationship to certain histopathic features of rheumatic heart disease. J. Exp. Med. 113:1-23.

3. Kaplan, M.H., Bolande, R., Rakita, L., and Blair,J. 1964. Presence of bound immunoglobulins and complement in the myocardium in acute rheumatic fever. N. Engl. J. Med. 271:637-645.

4. Lannigan, R., and Zaki, S. 1968. Location of gamma globulin in the endocardium in rheumatic heart disease by the ferritin-labelled antibody technique. Nature. 217:173-174.

5. Cunningham, M.W., et al. 1988. Human monoclonal antibodies reactive with antigens of the group A streptococcus and human heart. J. Immunol. 141:2760-2766.

6. Dale, J.B., and Beachey, E.H. 1985. Epitopes of streptococcal M proteins shared with cardiac myosin. J. Exp. Med. 162:583-591.

7. van de Rijn, I., Zabriskie, J.B., and McCarty, M. 1977. Group A streptococcal antigens cross-reactive with myocardium: purification of heart-reactive antibody and isolation and characterization of the streptococcal antigen. J. Exp. Med. 146:579-599.

8. Cunningham, M.W., et al. 1989. Human and murine antibodies cross-reactive with streptococcal $M$ protein and myosin recognize the sequence GLN-LYS-SER-LYS-GLN in M protein. J. Immunol. 143:2677-2683.

9. Dudding, B.A., and Ayoub, E.M. 1968. Persistence of streptococcal group A antibody in patients with rheumatic valvular disease. J. Exp. Med. 128:1081-1098.

10. Goldstein, I., Halpern, B., and Robert, L. 1967. Immunological relationship between streptococcus A polysaccharide and the structural glycoproteins of heart valve. Nature. 213:44-47.

11. Cunningham, M.W., and Swerlick, R.A. 1986. Polyspecificity of antistreptococcal murine monoclonal antibodies and their implications in autoimmunity. J. Exp. Med. 164:998-1012.

12. Krisher, K., and Cunningham, M.W. 1985. Myosin: a link between streptococci and heart. Science. 227:413-415.

13. Shikhman, A.R., Greenspan, N.S., and Cunningham, M.W. 1993. A subset of mouse monoclonal antibodies cross-reactive with cytoskeletal proteins and group A streptococcal M proteins recognizes $N$-acetyl-beta-D-glucosamine. J. Immunol. 151:3902-3913.

14. Shikhman, A.R., Greenspan, N.S., and Cunningham, M.W. 1994. Cytokeratin peptide SFGSGFGGGY mimics $N$-acetyl-beta-D-glucosamine in reaction with antibodies and lectins, and induces in vivo anti-carbohydrate antibody response. J. Immunol. 153:5593-5606.

15. Dale, J.B., and Beachey, E.H. 1985. Multiple, heart cross-reactive epitopes of streptococcal M proteins. J. Exp. Med. 161:113-122.

16. Fenderson, P.G., Fischetti, V.A., and Cunningham, M.W. 1989. Tropomyosin shares immunologic epitopes with group A streptococcal M proteins. J. Immunol. 142:2475-2481.

17. Cunningham, M.W., et al. 1992. Cytotoxic and viral neutralizing antibodies crossreact with streptococcal M protein, enteroviruses, and human cardiac myosin. Proc. Natl. Acad. Sci. USA. 89:1320-1324.

18. Dell, A., et al. 1991. Autoimmune determinants of rheumatic carditis: localization of epitopes in human cardiac myosin. Eur. Heart J. 12(Suppl. D):158-162.

19. Kraus, W.J., Seyer, J.M., and Beachey, E.H. 1989. Vimentin-cross-reactive epitope of type 12 streptococcal M protein. Infect. Immun. 57:2457-2461.
20. Antone, S.M., Adderson, E.A., Mertens, N.M.J., and Cunningham, M.W. 1997. Molecular analysis of $\mathrm{V}$ gene sequences encoding cytotoxic antistreptococcal/anti-myosin monoclonal antibody 36.2.2 that recognizes the heart cell surface protein laminin. J. Immunol. 159:5422-5430.

21. Shikhman, A.R., and Cunningham, M.W. 1994. Immunological mimicry between $N$-acetyl-beta-D-glucosamine and cytokeratin peptides: evidence for a microbially driven anti-keratin antibody response. J. Immunol. 152:4375-4387.

22. McCormack, J.M., and Cunningham, M.W. 1988. Recombinant human interleukin-2 (rIL-2) enhancement of antibody production by humanhuman hybridomas. Cell. Immunol. 115:325-333.

23. Adderson, E.E., Shikhman, A.R., Ward, K.E., and Cunningham, M.W. 1998. Molecular analysis of polyreactive monoclonal antibodies from rheumatic carditis: human anti- $\mathrm{N}$-acetylglucosamine/anti-myosin antibody $\mathrm{V}$ region genes. J. Immunol. 161:2020-2031.

24. Carpino, L.A., and Han, G.Y. 1972. The 9-fluorenylmethoxy-carbonyl amino protecting group. J. Org. Chem. 37:3404-3409.

25. Tobacman, L.S., and Adelstein, R.S. 1984. Enzymatic comparisons between light chain isozymes of human cardiac myosin subfragment-1. J. Biol. Chem. 259:11226-11230.

26. Margossian, S.S., and Lowey, S. 1982. Preparation of myosin and its subfragments from rabbit skeletal muscle. Meth. Enzymol. 85:55-71.

27. Quinn, A., Ward, K., Fischetti, V.A., Hemric, M.E., and Cunningham, M.W. 1998. Immunological relationship between the class I epitope of streptococcal M protein and myosin. Infect. Immun. 66:4418-4424.

28. Jaffe, E.A. 1984. Culture and identification of large vessel endothelial cells. In Biology of endothelial cells. E.A. Jaffe, editor. Martinus Nijhoff Publishers. The Hague, The Netherlands. 1-13.

29. Cunningham, M.W., Hall, N.K., Krisher, K.K., and Spanier, A.M. 1986. A study of anti-group A streptococcal monoclonal antibodies crossreactive with myosin. J. Immunol. 136:293-298.

30. Leung, D.Y.M., et al. 1986. Two monokines, interleukin 1 and tumor necrosis factor, render cultured vascular endothelial cells susceptible to lysis by antibodies circulating during Kawasaki syndrome. J. Exp. Med. 164:1958-1972.

31. Fujieda, M., Oishi, N., and Kurashige, T. 1997. Antibodies to endothelial cells in Kawasaki disease lyse endothelial cells without cytokine pretreatment. Clin. Exp. Immunol. 107:120-126.

32. Leung, D.Y.M., Collins, T., Lapierre, L.A., Geha, R.S., and Pober, J.S. 1986. Immunoglobulin $\mathrm{M}$ antibodies present in the acute phase of Kawasaki syndrome lyse cultured vascular endothelial cells stimulated by gamma interferon. J. Clin. Invest. 77:1428-1435.

33. Leung, D.Y.M., Moake, J.L., Havens, P.L., Kim, M., and Pober, J.S. 1988. Lytic anti-endothelial cell antibodies in haemolytic-uraemic syndrome. Lancet. 2:183-186.

34. Schett, G., et al. 1995. Autoantibodies against heat shock protein 60 mediate endothelial cytotoxicity. J. Clin. Invest. 96:2569-2577.

35. Beck, K., Hunter, I., and Engel, J. 1990. Structure and function of laminin: anatomy of a multidomain glycoprotein. FASEB J. 4:148-160.

36. Thoumine, O., Nerem, R.M., and Girard, P.R. 1995. Changes in organization and composition of the extracellular matrix underlying cultured endothelial cells exposed to laminar steady shear stress. Lab. Invest. 73:565-576

37. Davies, P.F., Remuzzi, A., Gordon, E.J., Dewey, C.F., and Gimbrone, M.A. 1986. Turbulent fluid shear stress induces vascular endothelial cell turnover in vitro. Proc. Natl. Acad. Sci. USA. 83:2114-2117.

38. Harasaki, H., Hanano, H., Tanaka, J., Tokunaga, K., and Torisu, M. 1978. Surface structure of the human cardiac valve: a comparative study of nor$\mathrm{mal}$ and diseased valves. J. Cardiovasc. Surg. 19:281-290.

39. Gospodarowicz, D., Greenburg, G., Foidart, J.M., and Savion, N. 1981. The production and localization of laminin in cultured vascular and corneal endothelial cells. J. Cell. Physiol. 107:171-183.

40. Ayoub, E.M., Taranta, A., and Bartley, T.D. 1974. Effect of valvular surgery on antibody to the group A streptococcal carbohydrate. Circulation. 50:144-150.

41. Gulizia, J.M., Cunningham, M.W., and McManus, B.M. 1991. Immunoreactivity of anti-streptococcal monoclonal antibodies to human heart valves. Am. J. Pathol. 138:285-301.

42. Ray, S.K., Putterman, C., and Diamond, B. 1996. Pathogenic autoantibodies are routinely generated during the response to foreign antigen: a paradigm for autoimmune disease. Proc. Natl. Acad. Sci. USA. 93:2019-2024

43. Limpanasithikul, W., Ray, S., and Diamond, B. 1995. Crossreactive antibodies have both protective and pathogenic potential. J. Immunol. 155:967-973.

44. Nissinen, M., Vuolteenaho, R., Boot-Hanford, R., Kallunki, P., and Tryggvason, K. 1991. Primary structure of the human laminin A chain. Biochem. J. 276:369-379.

45. Jaenicke, T., et al. 1990. The complete sequence of the human beta-myosin heavy chain gene and a comparative analysis of its product. Genomics. 8:194-206. 